\title{
Spinoza and the Relativity of Evil in the World
}

\author{
Muhammad Kamal \\ Asia Institute the University of Melbourne, Melbourne, Australia \\ Email:muhammad@unimelb.edu.au
}

How to cite this paper: Kamal, M. (2018) Spinoza and the Relativity of Evil in the World. Open Journal of Philosophy, 8 , 145-155.

https://doi.org/10.4236/ojpp.2018.83011

Received: February 19, 2018

Accepted: May 6, 2018

Published: May 9, 2018

Copyright (C) 2018 by author and Scientific Research Publishing Inc. This work is licensed under the Creative Commons Attribution International License (CC BY 4.0).

http://creativecommons.org/licenses/by/4.0/

\begin{abstract}
This article analyses the problem of evil in the world in the context of Spinoza's philosophical discourse. It deals with an important and urgent question: is there evil in the world or not? Drawing upon Spinoza's interpretation of the relationship between God and the world, I consider this dilemma by concentrating upon the pantheistic elements of his philosophy. I have discussed how Spinoza develops his arguments for the relativity of evil and its objective non-existence. This solution is derived from the way he identifies substance as the sole reality with God. I have also compared Spinoza's ideas with those of Plotinus by highlighting similarities in their respective understandings of the problem of evil.
\end{abstract}

\section{Keywords}

Substance, Evil, Relativity, Immanence, Transcendence

\section{Introduction}

Spinoza's philosophy revolves around the notion of a single substance. Substance is portrayed as the reality upon which the existence of everything stands. In this respect, its relation to the world can be defined in terms of identity and difference, in the sense that substance and the world are same and diverse. The world is the product of substance and yet also different from it. But the difference between substance and its product does not bring about an atypical reality.

With this portrayal of the nature of reality in Spinoza's pantheism the most enigmatic challenge is the existence of evil in the world. This challenge originates from the account of substance as the sole source of the being of all things. It is therefore natural to begin our discussion with the notion of substance and analyse its relation with the world, moving on next to an examination of the existence of evil in light of Spinoza's idea of the singularity of substance and its all-inclusiveness. 
By reducing everything to an infinite substance, the problem of evil in the world may appear more complex. This problem cannot be solved correctly unless we first understand the core of Spinoza's philosophy. It should also be remembered that from the outset Spinoza's account of the existence of evil in the world is in disparity with fundamental Judeo-Christian dogmas of faith and the paradigm of creation exnihilo. Yet this disparity only serves to render any discussion on the topic more interesting and challenging, because the problem of evil is not only philosophical. The question of its existence is of paramount importance for philosophers as well as theologians. As such, I attempt to examine the reality of evil in the world and discuss how the notion of substance as the source of the world repudiates the ontological possibility of evil.

\section{Spinoza's Worldview and Substance}

Spinoza's metaphysics begins with the assertion of the existence of a single substance as the concrete ground of all things. This single substance is also identified with God. Substance is defined as something that is conceived through itself, as something that exists in and of itself independent of the conception of anything else for its existence. Thus, it is self-caused and has no external source for its existence; "I understand substance (substantia) to be that which is in itself and it conceived through itself: I mean that, the conception of which does not depend on the conception of another thing from which it must be formed." (Spinoza, 1970: Def. 3, p. 1) Thereby, substance is uncreated and its essence necessarily includes its existence; "I understand that to be a cause of itself (causasui) whose essence involves existence and whose nature cannot be conceived unless existing." (Spinoza, 1970: Def. 1, p. 1) When we define the essence of substance we simply refer to its existence, because the existence of substance is inseparable from its essence. Whatever is causa sui brings about its own existence. There will be neither an ontological nor logical distinction between its essence and its existence. Its existence, for example, cannot be prior or posterior to its essence and vice versa. Such a kind of being must be infinite and eternal, otherwise its existence would be limited by something other than itself, which would make it finite.

In dealing with the number of substances, Spinoza also insists upon the existence of a single substance. If there is more than one substance, then they should be either identical or different. If they were identical then they wouldn't be distinguishable, and if they were different with nothing in common reciprocally, then one could not be the cause of the other. But having two substances with the same attributes would be meaningless, because they wouldn't be different in essence, in this case, they are not two substances but one. If two substances possess different attributes, they wouldn't be the same in essence and they would limit each other, then both becoming finite, which is in contradiction with the definition of substance as something infinite. There must, therefore, be only one substance as an infinite being possessing infinite attributes. In Ethics, Spinoza remarks that "Nor two or more substances can have the same attribute (Prop. 5), 
and it appertains to the nature of substance that it should exist (Prop. 7). It must therefore exist either finitely of infinitely. But not finitely. For (Def. 2) it would then be limited by some other substance of the same nature which also of necessity must exist (Prop. 7): and then two substances would be granted having the same attribute, which is absurd (Prop. 5). It will exist, therefore, infinitely." (Spinoza, 1970: Prop. 8, Proof, p. 4). Thus, there cannot be more than one substance having different attributes or sharing the same attributes.

Substance, as an infinite being, has attributes, which are infinite in number and kind. Of these infinite attributes, only two are known to the human mind, namely the attributes of thought and extension. This is a clear departure from the Cartesian tradition with which Spinoza was acquainted where these two attributes are called substances and exclude one another. For Spinoza, thought and extension with other unknown infinite attributes belong to a single substance. They can neither exist by themselves nor become substance.

Substance exists in such a way that it can be identified with God. This is a logical consequence of Spinoza's definition of substance as something infinite and uncreated, because in a theistic philosophical system only God possesses infinite qualities, "God (Deus) I understand to be a being absolutely infinite, that is, a substance consisting of infinite attributes, each of which expresses eternal and infinite essence." (Spinoza, 1970: Def. 6, p. 1). In Corollary 1, Proposition 14, Spinoza states, "Hence it distinctly follows that God is one alone, i.e., there is none like him, or in the nature of things only one substance can be granted, and that is absolutely infinite, as we intimated in the Note of Prop. 10." Accordingly, God is a single substance with infinite attributes and modes, at the same time, it is indivisible. If substance is divisible, its parts will either sustain the nature of substance or they won't. If they sustain the nature of substance, there will be plurality of substance. If they didn't sustain the nature of substance, then substance would no longer exist and hence becoming finite. Therefore, substance is indivisible and has no parts (Spinoza, 1970: Prop. 13, Proof, p. 10). In this way, indivisibility preserves the unity and singularity of substance.

This account of substance as having infinite attributes and its ensuing identification with God is imperative for our discussion of the existence of evil in the world because it is the core of Spinoza's metaphysical system. Richard Mason points out that God is not apprehended as a transcendent existent, or as a being among others but as the whole reality (Richard Mason, 1999: p. 37). God, as the only substance, has infinite attributes, and the attributes constitute His/Her divine essence. These attributes manifest themselves as modes to produce all existing entities. Thereby, everything would become a part of God, "Whatever is, is in God, and nothing can exist or be conceived without God." (Spinoza, 1970: Prop. 15, p. 11) Can we say that God is the totality of existing entities or transcends them? Since God has infinite attributes, it would be problematic to insist upon the nature of God in terms of totality, but then it is all-inclusive. There is nothing outside God's existence. In dealing with this problem, Harry A. Wolfson holds the view that Spinoza's God denotes the summum genus, containing all 
species (Harry A. Wolfson, 1962: p. 76). According to Edwin Curley, some scholars such as Pierre Bayle and Bertrand Russell, interpret the relationship between God and what is not God in terms of the relationship between substance and its accidents in much the same way as Descartes and Locke understood them (Edwin M. Curley, 1969: p. 4). Regardless of these different views on the nature of Spinoza's substance, we can say that the 'necessary' relationship between God and what is not God cannot be denied. Even when we think of Spinoza's God in terms of the Cartesian definition of substance, nothing could exist independently of God. Meanwhile, to define God's existence as the sum of infinite attributes, the difference between God and the world remain logical and not ontological because there would be no real distinction between God and the world, and nothing could therefore exist apart from God, "Whatever exists expresses in a certain and determined manner (Coroll. Prop. 25) the nature or essence of God, that is (Prop. 34), whatever exists expresses in a certain and determined way the power of God, which is the cause of all things, and therefore (Prop. 16.) from it some effect must follow (Spinoza, 1970: Prop. 36, Proof, p. 29). The world is the self-expression of God whose existence is necessary and infinite.

In his Short Treatise, Spinoza further stressed this necessary relationship between God and the world by describing God as natura naturans; a nature that produces its own modes and becomes the creator of natura naturata or the created nature (Spinoza, 1985: p. 91). The distinction between these two aspects of nature is again logical and not real, in the meantime no single mode in natura naturata is equal to God. Natura naturata as nature produced by God consists of two kinds of modes, the universal and the particular. The universal modes depend on God directly for their existence and Spinoza believes that the human mind can know only two universal modes, namely motion in matter and intellect in thinking existents. These universal modes are also produced by God from eternity and will remain for all eternity, whereas particular modes are dependent on the universal modes to exist and represent individual things. A human being, for example, Socrates, is a particular mode and as such, temporal. For this reason, Socrates is not a substance. This interpretation of a particular mode is discordant with Aristotle's definition of substance. For Aristotle, substance is a category divided into primary and secondary. The primary substance is an existent, (i.e., Socrates, a horse, a cat, and so on), without which the existence of other categories (or, accidents) would be unthinkable. The primary substance is neither asserted of a subject in a proposition nor present in a subject. Secondary substances are species and genera in which primary substances are included. (Aristotle, 1995a: 2b1-5) Aristotle also claims that substance is unchangeable. Change involves contraries, while substance has no contrary. In Physics, he has further divided substance into created (hylomorphic entities) and uncreated, such as God (Aristotle, 1995b: 225b1, 10-15). As we see, Spinoza not only disagrees with the Cartesian metaphysical dualism, he also rejects Aristotle's notion of hylomorphic (or primary) substances, because these entities cannot exist by themselves and rely on something else to exist. Spinoza, unlike Aristotle, does 
not identify substance with existents. Whatever Socrates has of thinking is only a mode of thought manifested from a divine attribute, and whatever he has of body and motion similarly belongs to another divine attribute. Socrates is a mode of substance and not a substance.

The denial of the real distinction between natura naturans and natura naturata has led some scholars to describe Spinoza's metaphysics as pantheism and atheism. Hegel states that Friedrich Heinrich Jacobi thinks Spinozism to be atheism because no distinction is made between God and nature (Hegel, 1995: p. 280). But Hegel defends Spinoza's position against this criticism and calls it "Acosmism"; the reduction of everything to God, because for Spinoza nothing other than God is real (Hegel, 1995: p. 281). It is also apparent why Spinoza is not interested in natural philosophy because for him nature is not distinct from God. Indeed, he has not even devoted any part of his philosophy to this topic. In Ethics he passes from a discussion on God to the philosophy of mind without dealing with natural philosophy. Spinoza works on the notion of God through substance as he reaches the conviction that nature in its macrocosmic as well as microcosmic mode is produced out of God and is an aspect of God's existence.

Spinoza's metaphysics, with its three levels of existence (God or substance, attributes and modes), represents a unified system, rejecting any distinction between them. The attributes are not separate entities from God but universal determinations of God's essence. Extension, for example, is an attribute and an extended thing is a mode of it. A mode, unlike an attribute, is not conceived through itself but through something else (Spinoza, 1970: Def. 5, p. 1), meanwhile, it is a manifestation of the attributes and the attributes constitute God's essence. As a consequence of this, whatever exists expresses, in a certain way the essence or the existence of God.

A key point to this discussion, which is important for our analysis of the reality of evil, is the immanence or transcendence of God. But once we understand Spinoza's interpretation of God's existence as the ontological source from which everything flows, the terms immanence and transcendence become necessarily inclusive. God is transcendent, for God is the ontological source of everything. In addition to this, God possesses infinite attributes and the physical nature is the manifestation of two attributes, namely, thinking and extension. In this way, God remains transcendent. Nevertheless, if God is the source of everything and whatever exists, is in God, then God must be the immanent cause of nature. Everything in nature and the whole of nature itself points to God as its source; "All things that are, are in God, and through God must be conceived (Prop. 15), and therefore, (Prop. 16, Coroll. 1.) God is the cause of all things which are in him: which is the first point. Again, beyond God no substance that is (Def. 3), a thing which outside God is in itself, can be granted (Prop. 14): which was the second point. Therefore, God is the indwelling and not the transient cause of all things." (Spinoza, 1970: Prop. 18, Proof, p. 18) Subsequently, God cannot be situated outside natura naturata, and what happens to nature would happen by God and in God. Nature necessarily becomes a self-manifestation and 
self-evolution of God. It is a living reality which proceeds entirely from God.

\section{The Reality of Evil in the World}

The difficulty in understanding Spinoza's philosophy does not lie in his interpretation of the nature of God's causality, for nothing can exist apart from God. The challenge posed in this interpretation and God's relationship with natura naturata is that of the existence of evil and its moral consequences. Does Spinoza believe in the existence of evil in the world? If evil exists at all, its existence is either derived from God or not from God. But neither assumption is ontologically possible because Spinoza's pantheistic position does not accommodate them. Any affirmation of the real existence of evil would become a clear negation of God's perfection and the denial of Spinoza's monistic-pantheism. If evil is derived from God, then God wouldn't be perfect. If it stands by itself and is independent of God, it would become a reality other than God. But can we deny the existence of evil in the world? What about those things and acts described as evil by us? To answer these questions, we deal with several arguments for the denial of the existence of evil in the world, which are all based on the way Spinoza interprets the nature of reality. First of all, if we assume that God is good and perfect and that evil is not produced by God then evil would necessarily be a reality different from and separate to God. This assumption, however, contradicts Spinoza's metaphysical interpretation of reality. To say that evil exists and is not derived from God, we deny the unity of God and assert the existence of multiple realities. To evade this contradiction, we can presume that if there is evil, then it should have been produced by God, because nothing can exist apart from God (see: Spinoza, 1970: Prop. 15, p. 11). But this assumption would make evil either an attribute or a mode of God. For Spinoza, God whose existence is necessary and infinite must be perfect. Imperfection is not a component of its existence; imperfection is a quality of finite beings. Spinoza argues for the existence of God through its perfection. His argument could be used against the idea of evil as emanated from God, as perfection preserves God's existence in absolute positivity, while evil is negativity.

God's perfection gives all things existence as well as essence (Spinoza, 1985, p. 87). If we accept the existence of evil in the world then we should also believe that its essence, like the essence of other entities, is produced by God, which is absurd. For this reason, if we accept the existence of evil in the world, it must be ontologically unreal. This is a reasonable outcome of the understanding of evil considering God's relationship with the world. To this point, it is important to understand how Spinoza addresses the problem of sins. For example, he asks, "why didn't God create men so that they should not sin?" In answering this question, he holds the view that evil and sinning are nothing but intellectual properties. There is no sin or evil in the world. Whatever we call it evil is evil only for us, "So the question now is whether good and evil should be regarded as beings of reason or as real beings. But since good and evil are nothing but relations, they must, beyond any doubt, be regarded as beings of reason. For one 
never says that something is good except in respect to something else that is not so good, or not so useful to us as something else. So one says that a man is bad only in respect to one who is better, or that an apple is bad only in respect to another that is good or better." (Spinoza, 1985: p. 92) From one perspective, particularly, when the whole of reality is comprehended, there could be no evil. Evil exists only in relation to the human mind. A human being as a finite mode makes value judgements and perceives something as good or bad. In this situation, there will be evil not as something objective, but only in thought. Spinoza has constructed his views on the non-reality of evil in an argument stating, that "all things which exist in Nature are either things or actions. Now good and evil are neither things nor actions. Therefore, good and evil do not exist in Nature." (Spinoza, 1985: p. 93) This explains that evil is neither universal nor objective. It is subjective and immanent to individuals. Thinking about evil as something in the world, outside the human mind, is rather not possible. It is a subjective value, which is neither a being nor a non-being. We can think of evil only in relation to a certain thing and a certain individual.

Wolfson has compared this position of Spinoza with that of some Jewish philosophers, such as Maimonides, Gersondies and other. He believes that the interpretation of the existence of evil in the world by these philosophers has significantly influenced Spinoza. This influence is apparent in his Short Treatise, where Spinoza asks how God as a perfect being could permit "confusion" in nature. The term "confusion" is also used by Maimonides to describe evil (Wolfson, 1962: p. 437). In answering this question, Spinoza denies the objective reality of 'confusion' or the non-presence of order in nature, for 'confusion' has no objective reality. It exists only in relation to us.

Wolfson has correctly detected the influence of these Jewish philosophers on Spinoza, but I believe that the roots of this interpretation of evil can be traced back further to Plotinus. Spinoza's position is reminiscent of the Plotinian interpretation of evil as described in the Enneads. The metaphysical system of Plotinus represents a system of necessary emanation of the world from God. All forms and phases of existence emanate from the essence of God, including "matter". The inclusion of matter in this process by Plotinus and the acceptance of "extension" as an infinite attribute of God by Spinoza can be understood as a commonality between the two thinkers and further one which influences their understanding of the existence of evil. But for Plotinus 'matter' is an element that causes things to fall short of perfection simply because matter is not form but "the Kind opposed to all Form is Privation or negation, and this necessarily belongs to something other than itself, it is no Substantial-Existence: therefore, if Evil is Privation or Negation it must be lodged in a subject deprived of Form: there will be no Self-Existent Evil." (Plotinus, 1952: I, 8, 11, p. 66). Evil is, in this respect, caused by matter. Form is a real existent and denotes positivity, while matter as such (not body) is void of all forms and denotes negativity. It lacks all determinations and hence is non-existent. When matter is the contrary of form, and form is real existence, matter becomes non-existence. Where there is no 
form, there is nothing that can be. We can say that form is a cause of actual existence. Philippus Villiers Pistorius has confirmed this by saying that matter, for Plotinus, does not exist (Pistorius, 1952: p. 121). Matter is the negation of the possibility of existence. Lloyd P. Gerson remarks that the notorious equation of evil with matter is based on the account of matter's relation to form, and its absolute privation (Gerson, 1994: p. 92). Anything without form is non-existent because form is reality. Since matter has no form, it is unreal and non-existent. It would be a negation, "not anything having a separate existence." (Plotinus, 1952: I, 8, 11, p. 67). It is striking to find in this context that matter is the principle of evil and yet at the same time to maintain that evil is subjective and relational. In fact, the soul and not matter should be the origin of evil. This does not mean the soul is evil but rather affected with evil and capable of making value judgements. It is worth mentioning that, Spinoza, unlike Plotinus, does not provide a negative account of matter, for extension is a divine attribute. He refrains from identifying matter with evil.

In his correspondence with Willem van Blyenbergh, Spinoza defends his idea of the relativity of evil and in letter 19, he writes, "...either that there is no such thing as sin or evil, or that God brings about that sin and that evil. But you don't explain what you mean by evil, and as far as one can gather from the example of Adam's determinate will, by evil you seem to mean the will itself insofar as it is conceived and determined in a particular way, or insofar as it is in opposition to God's command." (Spinoza, 2002: p. 808) Spinoza's letter is a response to Blyenbergh's question regarding Adam's willfulness consequent violation of God's command to refrain from eating of the Tree of Knowledge as recounted in the Hebrew Bible. The debate surrounding the existence of evil in this letter focuses on the idea of Adam's will to commit a sin or evil against the will of God and one displeasing to God. If we describe God as we perceive our own existence, feeling sympathy and antipathy and having emotions then God's nature and existence would be imperfect. But God's existence is ontologically different from human existence and has no attribute of passion. For if we know how passions are produced in the human psyche, we could never attribute them to God (Spinoza, 1952: Prop. 8, Note 2, p. 5). Since God has no passions, human actions neither make God happy nor angry because happiness and anger are passions and are not attributed to the perfect nature of God. This understanding of the nature of God however contradicts the doctrine of divine retribution and the theological viewpoint which claims that natural disasters are evil caused by God to avenge for the sins committed by human beings. Spinoza further clarifies this point, "Therefore since Adam's will or decision, regarded in itself, was neither evil nor yet, properly speaking, against God's will, it follows that God can be-or rather, according to reasoning you refer to, must be-the cause of it. But not insofar as it was evil, for the evil that was in it was simply the privation of a more perfect state which Adam was bound to lose because of his action." (Spinoza, 2002: p. 809) God is the cause of Adam's will, but not the cause of his decision to committee a sin, because Adam's sin or evil act is a mere privation and negativity. 
None of these qualities are attributed to God. Does this mean that evil pertains to the essence of finite beings? Can we say an individual who commits a sin has a sinful essence? Spinoza attends to the human essence as a finite mode of God. For this reason, the human essence is in a state of positivity, because it is real. By contrast, evil is unreal. When this state of positivity is guided by "reason" it will desire a greater good. Emotion, unlike reason, will not guide individuals to choose a greater good. In this context and in drawing a distinction between reason and emotion, Spinoza divides individuals into two kinds, free and slaves. The former follows reason and the latter controlled by emotion. The slaves of emotion become ignorant of a greater good (Spinoza, 1970: Prop. 66, Note, pp. 186-187). In interpreting this point Gilles Deleuze remarks that an individual is not bad or criminal according to the affections s/he has, but according to the affections he does not have (Deleuze, 1988: p. 38). Evil, accordingly, is in the order of the relationships or in a compression of different affections. On this ground, Spinoza develops another argument based on the inadequacy of our knowledge of evil. He argues that our knowledge of evil is "inadequate", because "it is pain itself in so far we are conscious of it." (Spinoza, 19970: Prop. 64, p. 185) Pain is not something through itself, but a transition to a lesser perfect and subjective state of existence. Accordingly, our knowledge of evil is reliant on inadequate ideas. Only reason is capable of producing adequate ideas. A free individual who is guided by reason alone has adequate ideas from this we may conclude that free individuals have no conception of evil (Spinoza, 1970: Prop. 68, Proof, p. 187).

The idea of relativity undermines the reality of evil in the world. We can say more specifically that evil is neither an existent nor that it pertains to the human essence. The notion of evil is created by human beings and exists only in relation to various other states of existence. When we compare these states of existence some of them appear to be less perfect than others. A less perfect state, in particular one that prevents us from achieving a greater good, would be perceived as evil. "A good thing which prevents us from enjoying a greater good is in truth an evil, for good and bad is said of things (as we showed in the preface of this part) in so far as we compare them one with the other, and (for the same reason) a lesser evil is in truth a good. Wherefore (Coroll., Prev. Prop.) under the guidance of reason we desire or follow only the greater of two things which are good and lesser of two which are evil." (Spinoza, 1970: Prop. 65, Proof, p. 186) There is no evil as such, but a lesser good, which prevents us from obtaining a greater good. This interpretation of evil by Spinoza is again reminiscent of Plotinus' way of thinking about evil. In the Enneads, Plotinus writes, "Perhaps Evil is merely an impediment to the Soul like something affecting the eye and so hindering sight." (Plotinus, 1952: 1, 8, p. 67) Here, whatever is an impediment is not evil but something that stands in relation to a greater good or it is perceived by us as evil because it becomes an impediment to our progress. These two thinkers, for the same philosophical reasons discussed above, deny the existence of evil. First, by thinking of the world as God's self-expression and second, by defining evil as a lesser good. But the denial of evil can also lead to the denial of goodness. There 
is evil as a lesser good in relation to a greater good. What is denied here is not evil but a lesser good, which is at the same time a greater good for a state prior to or inferior to it. Since evil is relational and has no objective reality we can also draw the same conclusion for the existence of goodness. Hence, evil and goodness can be no more than accidents and their meanings should be understood in connection to "prevention", "privation" from, and "contrary" to a greater good.

\section{Conclusion}

Spinoza's philosophical discourse focuses on the existence of a single and perfect substance. This single reality does not permit objectivity of evil in the world. All existing entities are multiple modifications of the attributes of substance. Consequently, if we concede the existence of evil, it must be either an attribute or a mode of an attribute. But since substance is perfect, the admission of evil in the world is impossible. On the other hand, this conviction does not endow evil with a different or separate reality, because, Spinoza substance is the only reality and is free from otherness otherwise the unity of substance would be jeopardised. Therefore, in both cases it is impossible to fathom the existence of evil in the world. So then why do we still attribute evil to certain things? Spinoza has given a viable answer to this question. He addresses the problem of evil in terms of relativity and intellectual property. This solution, as discussed above, is parallel to Plotinus' characterisation of evil as privation and a lesser good that prevents us from attaining a greater good. Thus, for Spinoza, evil has no place in the world. Whatever is described as evil is relational and it is evil only for us, not in and of itself.

\section{References}

Aristotle (1995a). Categories. In J. Barnes (Ed.), Complete Works of Aristotle (Vol. 1). Princeton and New Jersey: Princeton University Press.

Aristotle (1995b). Physics. In J. Barnes (Ed.), Complete Works of Aristotle (Vol. 1). New Jersey: Princeton University Press.

Curley, E. M. (1969). Spinoza’s Metaphysics: An Essay in Interpretation. London, Oxford: University Press. https://doi.org/10.4159/harvard.9780674330450

Deleuze, G. (1988). Spinoza: Practical Philosophy (translated by Robert Hurley). San Francisco, CA: City Lights Books.

Gerson, L. P. (1994). Plotinus. New York: Routledge.

Hegel, G. W. F. (1995). Lectures on History of Philosophy (Vol. 3, translated by E. S. Haldane and Frances H. Simson). Lincoln and London: University of Nebraska Press. (Reprinted)

Pistorius, P. V. (1952). Plotinus and Neoplatonism: An Introduction. Cambridge: Bowes and Bowes.

Plotinus (1952). The Enneads (translated by Stephen MacKenna and B.S. Page). Chicago, London and Toronto: William Benton Publisher.

Richard, M. (1999). The God of Spinoza: A Philosophical Study. Cambridge: Cambridge University Press. 
Spinoza, B. (1970). Ethics (translated by Andrew Boyle, introduction by T. S. Gregory). London, New York: Everyman's Library. (Reprinted)

Spinoza, B. (1985). Short Treatise on God, Man and His Well-Being. In E. Curley (edited and translated), Collected Works of Spinoza (pp. 46-156). Princeton, NJ: Princeton University Press.

Spinoza, B. (2002). Complete Works (translated by Samuel Shirley, edited with introduction and notes by Michael L. Morgan). Indianapolis/Cambridge: Hackett Publishing Co. (Reprinted)

Wolfson, H. A. (1962). The Philosophy of Spinoza (Vols. 1\&2). Massachusetts, London: Harvard University Press. (Reprinted) 